somewhat peculiar, though in the complete margin and number of segments it agrees with Parabolinella. To Olenus used in a generic sense this species may certainly be referred. Salter's ${ }^{1}$ species with the same name is distinct from Belt's, but belongs to the Olenidæ.

From the above revision the so-called species of Conocoryphe in Britain should be designated as follows :-

\title{
Euloma abditum.
}

Solenopleura applanata.

Otenus? bueephalus.

Conocoryphe (Bailiella) bufo.

Ctenocephalus coronatis.

Solenopleura? depressa.

Peltura, sp. [ = C.? ecorne? (Ang.), Salter].

Conocoryphe? Homfrayi.

Olenoides humerosus.

Apatokephalus invitus.

Olenus (Parabolinella?) longispina.

The three species of which the genera even are doubtful are $C$.? olenoides, C. vexata, and $C$. viola. But none of these three can be attributed to Conocoryphe, and their true position must be left to the future to decide.

The distribution of the tabulated forms is as follows :-

HARLECh SERIES.

Conocoryphe Lyelli.

Ctenocephalus (Hartella) solvensis.

Menevian.

Solenopleura applanata.

Conocoryphe (Bailiclla) bufo.

Ctenocephalus coronatus.

Conocoryphe? Homfrayi.

Olenoides humerosus.

Conocoryphe? perdita.

Solenoplema? iariolavis.

Lingula Flags.

Euloma abditum.
Conocoryphe Lyelli.

Peltura? malvernia.

Euloma snonile.

Conocoryphe? perdita.

Olenus (Parabolinella) Planti.

Olenus (Cyclognathus) simplex.

Ctenocephalus (Hartella) solvensis.

Solenopleura? variolaris.

Angetina verisimilis.

Olenus (Parabolinella?) Williamsoni.

The genus Conocoryphe, sens. str., is thus seen to be confined in Britain to the Lower and Middle Cambrian beds.

\section{V.-On the occurkence of a Blue Amphibole in a Hobndiende Kersantite from Co. Down.}

By Henrx J. Seymour, B.A., F.G.S., of H.M. Geological Survey of Ireland. (Communicated by permission of the Director-General.)

TN connection with the revision of the Silurian area in Ireland, at present in progress by the staff of the Irish branch of the Geological Survey, a number of rock-specimens of the dykes occurring on the coast of Co. Down were lately petrographically examined by the writer, who detected in one of the slices a blue amphibole of secondary origin. As a mineral of this kind was not hitherto known to occur in sitú in Ireland, it may be of interest to put its discovery on record here and to give also a few details respecting its characteristics.

1 Cat. Camb. Sil. Foss. Woodw. Mus., 1872, p. 12.

DBCADE IV.-VOL. VIT.-NO. VI. 
The rock in which it occurs appears as a dyke (in Upper Silurian sediments) ${ }^{1}$ on the shore one-eighth of a mile south of the point where the letter $B$ in South Bay is engraved on the map; three miles south-east of Portaferry $\left(1^{\prime \prime}\right.$ sheet 49$)$, and near the spot where the small road south of "Tara Fort' reaches the coastline. On the original 6 inch working maps of the Survey it is represented ${ }^{2}$ as a double dyke, with the ends of each portion in parallel contact, the northern limb forming a semicircular bend in the middle and enclosing a small area of sedimentary rocks. The combined width of the two portions is approximately 20 inches.

In the hand-specimen the rock is of a dull greyish-green colour, and possesses a medium-grained crystalline structure. Bronzy mica is the mineral most readily noticeable, and a few octahedra of magnetite may be seen with the aid of a pocket lens. Its specific gravity was found to be 2.85 in its present slightly decomposed condition. Under the microscope it is seen to consist essentially of a dark mica, with subordinate green hornblende, and an aggregate of felspar crystals. Accessory and secondary minerals also present are apatite, magnetite, a blue amphibole, chlorite, and several calcareous pseudomorphs, apparently after augite or hornblende phenocrysts, more probably the latter.
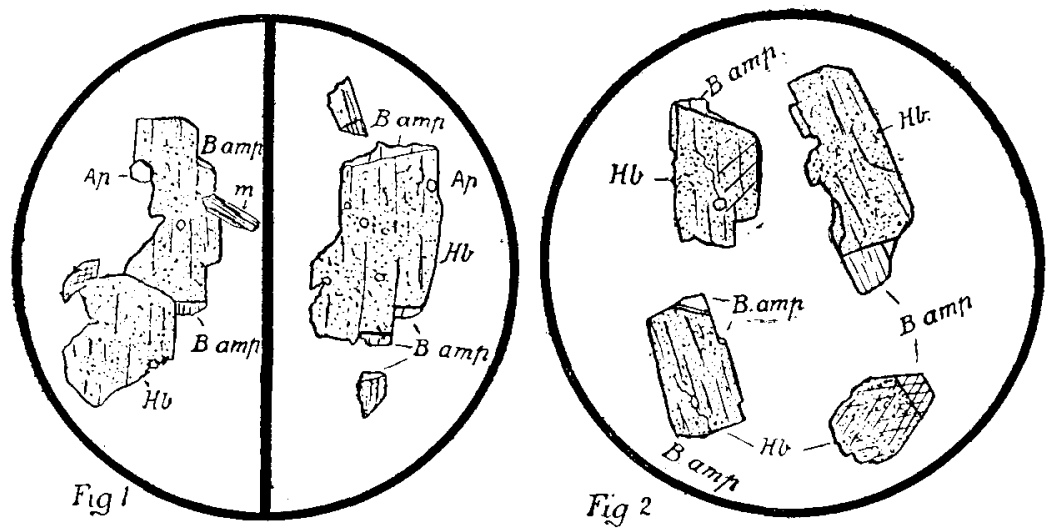

Minerals. - $F b$. green hornblende. $m$. biotite. Ap. apatite. B. amp. blue amphibole.

Fra. 1 shows two large hornblende phenocrysts, with additions of secondary blue amphibole on some of their terminal faces. $\times 45$ diams.

FIG. 2 shows four crystals which exhibit the typical mode of occurrence of the blue amphibole. That in the S.E. quadrant shows a basal section with the clinopinacoid of the primary green hornblende replaced by the blue amphibole. The crystal in the S.W. quadrant shows a narrow pale-blue zone between the green hornblende and the normal blue amphibole. $\times 45$ diams.

1 These sediments were originally regarded as Lower Silurian. The recent revision (by Mr. F. W. Egan), however, shows them to be Upper Silurian. Report of Director-General of Geol. Survey, Appendix to 44th Report, Dept. of S. and A., p. 365 .

${ }_{2}^{2}$ By Mr. W. A. Traill, who mapped the dykes in this district. See Memoir of Geol. Survey to accompany $1^{\prime \prime}$ sheets 49,50 , and 61 (1871), pp. 6 and 43. 
The biotite forms small (about $0.40 \mathrm{~mm}$.) hypidiomorphic crystals scattered fairly abundantly and evenly throughout the slide. Sections at right angles to the cleavage planes are strongly dichroic (almost colourless to greenish brown), and are frequently bent into curved forms. Narrow bands of calcite are occasionally noticed between the lamellæ. The mineral is here and there altered to chlorite on its edges, and also to a less extent along cleavage cracks. Sections parallel to the basal plane give a uniaxial interference figure and show an outer rim of a much darker colour than that of the interior of the crystal.

The felspars occur in medium-sized allotriomorphic crystals which are rather altered and mostly micropoikilitio with numerous minute inclusions. In their present condition the exact species is not satisfactorily determinable, but repeated twinning is noticeable in several of the less altered crystals, and they would seem to be essentially plagioclase.

Apatite is an abundant constitnent in the rock, and occurs as inclusions in the biotite, plagioclase, and in the green hornblende.

This latter mineral is also hypidiomorphic, and appears to be slightly posterior in date to the biotite, small crystals of which it sometimes includes. Sections parallel to the principal axis attain a length of $0.60 \mathrm{~mm}$. The pleochroism is fairly strong, the tints varying from yellowish to a dull dark green. Basal sections exhibit the characteristic six-sided forms with well-defined cross cleavages intersecting at an angle of about $124^{\circ}$. The blue amphibole occurs mostly as a secondary addition to, but partly also as a replacement of, the primary green hornblende, and has grown in crystallographic continuity with it. The cleavage lines are usually continuous in both varieties, but are finer and sharper in the blue amphibole. In most cases this latter is added to the clinopinacoidal or terminal planes of the green variety, and occurs also, but less often, along cracks in the interior of these crystals. The secondary enlargement is quite limited in extent and seldom exceeds $0.10 \mathrm{~mm}$. in greatest length, the average being rather below this figure. The junction line between the two varieties is generally distinct, and they are also sharply marked off from one another by their notably different pleochroism. Exceptionally a very narrow band or zone of material of a much paler blue colour than the normal blue amphibole occurs between the latter and the green hornblende. The drawings show the characteristic mode of occurrence of the secondary mineral in question. Owing to its small size it does not present facilities for satisfactorily determining its optical properties, but in so far as it is possible to do so, they would appear to be as follows. Sections approximately parallel to the clinopinacoid show that the extinction angle is about $15^{\circ}$, and that this takes place on the opposite side of the vertical axis to that of the green hornblende to which it has been added. Observations with the quartz wedge appear to prove that this direction of extinction corresponds also with the axis of maximum elasticity. The pleochroism is strong and is as follows: $\mathrm{a}=$ sky-blue, $\mathrm{b}=$ pale reddish-violet, $\mathrm{c}=$ pale yellowish. The absorption formula is $a>b>c$. 
In some isolated cases the blue amphibole shows wavy extinction under crossed nicols, due apparently to a gradual change in chemical composition during its formation. It was found impracticable to isolate material for chemical analysis, but there can be no reasonable doubt that it belongs to the soda amphibole group of which riebeckite and arfredsonite are typical examples.

The occurrence of a secondary blue amphibole under conditions exactly similar to those just detailed above has been described by Dr. Whitman Cross ${ }^{1}$ in the case of an allied rock from Colorado. A. C. Lane ${ }^{2}$ also records a similar occurrence in a syenite from Michigan. More recently J. S. Flett ${ }^{3}$ notes the presence of a secondary blue amphibole in cracks in crystals of hornblende in one of the lamprophyre dykes of the Orkney Islands. The mineral from the Co. Down corresponds so closely in every particular with those from the two American localities aboved cited, that the writer has little hesitation in referring it to the same species. The mineral described by Cross has been called crossite by $\mathrm{Ch}$. Pelache, ${ }^{4}$ who also has described a species with identical optical properties. Dr. Cross, however, in a later publication ${ }^{5}$ states that the mineral in question is considered to be arfvedsonite by Dana, ${ }^{6}$ Brögger, ${ }^{7}$ and Rosenbusch. ${ }^{8}$ It may be noted further that Iddings, in his translation ${ }^{9}$ of Rosenbusch's work, describes the secondary amphibole of Cross in the context between glaucophane and riebeckite, which position the at any rate optically similar species of Pelache ${ }^{10}$ occupies by virtue of its intermediate chemical composition. Rosenbusch $^{11}$ notes the occurrence of a blue amphibole in a minette from Wachemback in the Vosges, the rock belonging to the same group as the Co. Down specimen.

\section{VI.-ON Rhadinichtays afonensis, Egerton, and its Distribution in the Yorkshire Coalfield.}

By Edgar D. WellburN, L.R.C.P., F.G.S., F.R.I.P.H., etc.

TIHIS species was first described by Sir P. De M. Grey Egerton ${ }^{12}$ as 1 Palconiscus monensis, in 1850, from detached scales from the Coal-measures of Anglesey. Subsequently, Dr. R. H. Traquair ${ }^{13}$ proved that the proper position of the fish was in bis genus Rhadinichthys. Up to this date only detached scales had been known, but in the paper just mentioned Dr. Traquair described specimens showing many points in the structure of the fish which had been

\footnotetext{
1 Amer. Journ. Sci., vol. xxxis (1890), p. 359 et seq.

2 Amer. Journ. Sci., vol. xlii (1891), p. 505.

S Trans. Roy. Soc: Edinburgh, vol. xxxix (1900), pt. iv, p. 884.

4 Bull. Dept. Geol. Univ. California, 1894, p. 181 et seq.

5 16th Ann. Rep. U.S. Geol. Survey, 1894-95, pt. ii, p. 30.

- System of Mineralogy, 6th edition, 1892, p. 402 .

7 Die Gesteine der Grorudit-Tinguait-Serie, 1894, p. 33.

8 Die mikro. Phys. der petro. wichtigen Min., 3rd ed., 1892, p. 567.

9 Translation of the last work by Iddings, 1898, p. 270.

10 Loc. cit., p. 189.

11 Mikro. Phys, d. massigen Gesteine, 1896, p. 510.

12 Quart. Journ. Geol. Soc., rol. vi (1850), p. 5.

13 Proc. Roy. Phys. Soc. Edinb., vol. iv (1878), p. 241.
} 